\title{
The role and importance of functioning institutions of justice in fighting crime
}

\author{
Xhevdet Halili, MSc, PhD Candidate \\ Law Faculty, University of Prishtina \\ Director of the Kosovo Law Centre, Republic of Kosova
}

\begin{abstract}
Justice authorities are one of the main pillars on which rests the basis of the functioning of most other institutions within a state. As is known the justice authorities, but that within their authority to have the preservation of public peace and order, have and fighting and preventing crime in general. Institutions that have special role in the fight against crime are numerous, but we have dealt only some of the key institutions involved in combating and preventing criminal phenomena in general and in particular in Kosovo.
\end{abstract}

Ranging from the role of police in preventing and fighting crime as a phenomenon of harmful and dangerous to society then continued with the role and importance of the state attorney in fighting and preventing crime in Kosovo, to continue in the role and importance of courts in the prevention of crime.

Also, is treated the protection of human rights in general within the legal system in Kosovo, addressing the issue of respect for human rights and the possible limits of institutions that have officials in respect to human rights in general.

Keywords: institutions of justice; police; courts; prosecution; crime prevention and fighting; and human rights.

\section{Introduction}

The functioning of justice institutions is very important and that almost vital for fighting and preventing crime in general. As a role but also the importance of their function is a prerequisite for the functioning of justice institutions and the protection of human rights.

Therefore, in this paper we will focus in the field of combating crime, the field of security and defense of human rights, all based on creating welfare and protection of human rights which are is guaranteed by national legislation with international as well.

The views, opinions and desires that institutions in the field of justice, but not only these, to be perfect, are more illusion. Yet there are states that have much more to consolidate these institutions in relationship to others. Kosovo in the group of those countries that consolidation of these institutions leaves much to be desired. 
It is true that everyone deals with crime, but unfortunately mostly be those who commit crimes, but we as researchers in this field based on the science and practice in this area should focus on some important points that important professional and efficient functioning of judiciary in general, but also in the case of Kosovo.

In this paper will be addressed among others the role of the police in crime prevention and fighting, the role and importance of the state prosecutor in the prevention and combating of crime and the role and importance of the courts in combating and preventing this phenomenon. Also in focus to tackle this problem are the protection of human rights and freedoms.

\section{The functioning of some institutions of justice}

Organs and their functioning in Kosovo are quite many in number, but some of them deal more, or directly to the prevention and combating of crime, therefore we will stop exactly in their elaboration in this paper.

The functioning of the criminal justice system must ensure the protection of the interests of the victim. Indeed, the criminal policies have directed towards crime prevention. ${ }^{1}$ One contemporary criminal policy guidelines is that the means and methods of fighting crime to respect democratic principles, the rule of law and human rights. ${ }^{2}$ The main bodies involved in fighting and preventing crime are numerous, but we will address some of them, such as police, state prosecution and courts, which also will talk more extensively later in the paper.

\section{The role of the police in combating crime}

The role of police in preventing and combating crime is undisputed, but, based on its competencies, this body is called, in combating these criminal phenomena. Depending on the legislation, some states have also specialized institutions for the prevention and combating of crime. Bodies charged by law with preliminary investigations are prosecutor and judicial police. These bodies, within certain powers necessary to conduct investigations relating to the criminal prosecution. ${ }^{3}$ The prosecutor leading the investigation and the judicial police. Judicial police activity as procedural criminal offense as is done by the entities and bodies to which the law imposes the duty to investigate from the moment you become aware of the offense. ${ }^{4}$ The role of the police as an institution competent in maintaining public order and peace, in preventing and combating crime and other duties, the police are determined by laws

\footnotetext{
${ }^{1}$ Latifi, Vesel, Criminal Policy, Pristine, 2008, p. 108.

${ }^{2}$ Ibid.

${ }^{3}$ Begeja Skender, Criminology, Volume I, Tirana, 2001, p. 20.

${ }^{4}$ Ibid., p. 21.
} 
and regulations or internal principles of police work. The Constitution of the Republic of Kosovo is considered as advanced legal basis, which guarantees the promotion of democratic institutions in accordance with international principles, including international conventions dealing with the protection of human rights. ${ }^{5}$ Based on the current legal situation, Kosovo police is the only institution in the security sector which is mandated police and who holds the right to use force. Among its powers listed: protection of life, safety and property of all individuals: protection of human rights and fundamental freedoms of all citizens and other persons within its jurisdiction; take care to maintain order and public safety, crime prevention, traffic safety and border control. ${ }^{6}$ But, despite police work should not be measured by describing the daily activities or writing weekly and monthly reports, but it must be measured with the work for which they are authorized by law, all police officers, "the police official has any attributes judicial police in accordance with the criminal procedure code and other laws applicable in Kosovo. ${ }^{7}$ In accordance with the work of the police should be measured based on:

- Detecting crime rate;

- The way they gather evidence;

- The undertaking in the detection of crime and

- On how effective the police in apprehending offenders, etc.

Problems faced every day, this important institution in fighting and preventing crime, are as follows:

- Lack of necessary and sufficient to fight crime;

- Lack of professional capacity in sensitive areas to combat crime;

- Promotions are not taking into consideration the merits and professional police work (or nepotism in the promotion);

- Until the most severe forms, such as bribery, etc.

There are various ways by which to measure the effectiveness of police work, but the most obvious is the calculation of the percentage of detection of offenses, and through this calculated efficiency of police work in the detection of such offenses; it is a way of measuring the performance of the police in combating and preventing crime.

Preventing crime in general means a system of government measures, social or special run for detection, containment, weaken, neutralize the causes and conditions of crime in general, his specific types or specific offenses and no involvement in crime or not to return into society of persons, living or whose behaviors indicate the real possibility of

\footnotetext{
${ }^{5}$ Article 3, paragraph 2, of the Constitution of Kosovo, since 2008.

${ }^{6}$ Kosovo Center for Security Studies (KCSF), Monitoring and evaluation of good governance in the security sector in Kosovo, Pristine, 2012, p. 29.
}

${ }^{7}$ Halili, Xhevdet, Introduction to the Law of Police, Pristine, 2012, p. 19. 
involvement in crime. ${ }^{8}$ But, in any given society advantage of preventive activity, the application of comprehensive measures to avoid criminal activity. ${ }^{9}$

But all these actions of police work, nor can think, and not be carried out without the help of citizens, and unfortunately in practice some silent, some not dare to speak, of a very small number are willing to cooperate with the investigation and prosecution. It should also be organized round tables, conferences and campaigns to raise public awareness for their cooperation with the police in order to combat and prevent crime.

\section{The role of the state attorney in fighting crime}

Even if the police are efficient, or illuminates all cases, these cases should be sent then or should gototheprosecutor, theprosecutorofthestate institution hasgreatcompetence in theinvestigation, theneed toassessthelevelofprosecutionsandinvestigationsconducted. Prosecution, as the state agency that operates the public interest or the state, historically linked to the French bourgeois revolution, although its beginnings date back to the middle Ages. French bourgeois revolution intentions have gone into the development of prosecution prosecution body; with this feature tend to be separated from the function of the trial. ${ }^{10}$ Repressive function of the state attorney in our legal system is precisely regulated by law. The state prosecutor, as one of the three basic subjects in criminal proceedings, is the carrier of the prosecution function, which is of great importance and political criminal, because it is a guarantee for the preservation of public and private interest, in case of violation or danger this right. Therefore, to successfully realize the function of the state prosecuting attorney has the right and duty to undertake a range of concrete activities. ${ }^{11}$

Under the law of the state prosecutor, provided that: "The state prosecutor means competent and independent institution responsible for the prosecution of persons accused of committing criminal acts and other acts within the law." ${ }^{12}$ Institutions which operate within state prosecution are as follows: basic prosecution, prosecution appeals, the special prosecutor, chief State Prosecutor's office and any other organizational unit that can be created to exercise prosecutorial functions under the law. Regarding cooperation with other bodies such as the police and courts, but also with other institutions aimed at preventing and combating crime, the law in question noted that: " The state prosecutor cooperates with state and other public entities and private activities related to the education of society with the objective

\footnotetext{
${ }^{8}$ Gjonça Lion, Gjonçaj Genc, Criminology, Tirana, 2009, p. 23.

${ }^{9}$ Rica, Nicholl, Judicial Police as Subject of Criminal Proceedings, Tirana, 2011, p. 116.

${ }^{10}$ Elmedin, Muratbegović, Compendium of Crime Prevention and Crime Control, Sarajevo, 2007 p. 126.

${ }^{11}$ Sahiti, Ejup, Murad, Rexhep, Criminal Procedure Law, Pristine, 2013, p. 181.

${ }^{12}$ Article 2, paragraph 2, section 2, Law on State Prosecutor of the Republic of Kosovo (LSPRK's).
} 
of raising awareness about the law and prevention of criminal acts." ${ }^{13}$ The state prosecutor has pronounced role in preventing and combating organized crime, as a great evil for society and the state. In the state prosecutor's job is very much present and finds its expression in many situations, the principle of legality, but, in certain situations, this principle limited or interlaced and another principle, the principle of opportunity. The state prosecutor in Kosovo organized and functions in accordance with the law of the state prosecutor, as well as the law on the special prosecutor in cases where it can be applied. Despite the situations and circumstances in which the institution operates state prosecution, they must justify and argue cases, when one lie investigations, suspend or waive the investigation, because the law provided when the prosecutor can take an action or another, but often these actions are taken even when not sufficiently justified. Prosecution has not enough context, compared to the percentage required for works which she is charged, but the institution as police are overloaded with cases and no prospect physical work priority, which means that such cases are cases where citizens were the measure of detention and those deprived of liberty, of these known cases are treated with priority cases from this institution. So when it comes to the protection of human rights, our citizens do not care priorities of the police and prosecution, he provided care to the protection of personal rights and property, so that in no case must not be neglected our institutions.

The legal system of Kosovo is a modern and which basically defines and protects fundamental rights and freedoms of the person and conforming to international conventions. ${ }^{14}$ In this respect we rightly conclude that the legislative basis is quite advanced in Kosovo. But we also learn every day, especially from Criminology, Criminal Procedure but also by what, when criminal charges should be exercised, as well as measures to be undertaken numerous investigations and gather more evidence and facts, under which the defendant is charged, despite this, in many cases, the court imposes a judgment of acquittal, in the absence of evidence.

\section{The role of the judiciary in combating crime}

The role and importance of this institution is of crucial importance for the functioning of the rule of law in a country, and for the rule of law and respect for human rights. As the Professor Gruda human rights and fundamental freedoms traditionally been treated as a matter of domestic jurisdiction (national competence), and therefore their regulation by laws made, statement or constitution. They will also be transferred to the international arena after World War II. ${ }^{15}$ Therefore, the excess of the limits of the national human rights calls for their treatment with floors and international conventions, and helps the judges in their work in defense of human rights, anywhere.

\footnotetext{
${ }^{13}$ Section 8, of the LSPRK's.

${ }^{14}$ Demolli Haki, Some Specifications of the Legal System of the Republic of Kosovo, Journal "Right", Pristina, Nr.1/2010, p. 33.

${ }^{15}$ Gruda, Zejnullah, International Protection of Human Rights, Pristine, 2001, p. 13.
} 
Today, in the world, there are cases when different institutions involved in preventing and combating crime treat cases, depending on the gravity or nature of those offenses. Therefore, now is the time that the prosecution authorities, intelligence and judgment, to treat in the same way, all offenses, regardless of whether it is a criminal offense committed in the field of communications, ecology, computer crime, or has committed a murder, abduction, or fraud, for offenses as the first group and the second group these cause certain consequences in society, so as such they should also be treated uniformly and the same. Kosovo Judicial Council by controlling the work of judges provides that courts in Kosovo be independent, professional and impartial judicial system in order to be more efficient in the fight against organized crime and other forms of criminality. Prosecutors and courts are the institutions responsible for the prosecution of offenders, their adequate punishment, confiscation of property and assets acquired through criminal activities. In the institutional context, an important role in preventing and combating organized crime also play local and international partner institutions, which are present in Kosovo, but also those who are abroad. ${ }^{16}$ All these cannot be handled by specialized bodies such as the police, prosecution and judiciary, without supervision and evaluation of the country's highest authorities.

If these bodies analyzed the efficiency of the police, prosecution and judiciary, and penal policy since found lapses or inadequate work, and proposed legislative measures by the supervisory bodies. Intensive communication and quality of cooperation between police investigators, prosecutors and judges, two elements are necessary to achieve an efficient and functional rule of law. Institutional triangle can only be done if there is a strong coordination between the three institutions. ${ }^{17}$ So, this triangle of functioning of state institutions in the field of security, has to do with the police, prosecution and courts, and operation of this triangle properly, meaning the implementation of legality and authentically functioning of state institutions and security judiciary in that country. It is only natural that if cooperation does not work: police, prosecution and court, then the opportunity to have an investigation, prosecution and adjudication fast, efficient and realistic, greatly reduced. Therefore, it is necessary to work hard to increase this cooperation and advance further, with the only purpose to have criminal processes more efficient and successful.

Interagency cooperation and coordination between institutions is a precondition for a more efficient work in preventing and combating organized crime, especially in the process of exchange of information, exchange of experiences and joint actions or operations. Therefore, institutional cooperation and coordination includes a series of measures aimed, to become:

\footnotetext{
${ }^{16}$ State Strategy of the Republic of Kosovo, Organized Crime and Action Plan, 2009, Pristine, p. 13.

${ }^{17}$ Kosovo Institute for Policy Research and Development, KIPRED, p. 11.
} 
- Strengthening cooperation and coordination within the institution;

- Strengthening interagency cooperation and coordination;

- Strengthening cooperation and coordination with EULEX. ${ }^{18}$

By preventing and combating crime, it is necessary to organize and hold various activities in order to raise awareness of personnel responsible institutions and the general public about the consequences that causes criminality in general. Institutions of the Republic of Kosovo is committed to fighting all forms of crime, including, but not limited to: the fight against drugs, human trafficking, smuggling of migrants, weapons, fuel, alcohol, works of art, works cultural heritage. But, as these strategies are sufficient if they are not implemented in practice. It is true that the strategies are just a worthless piece of paper when they are applied in practice by the institutions which have promulgated and adopted as documents or strategy. Therefore, it is necessary to pass from words to action and grow even more war against organized crime in Kosovo. Not exactly the full implementation of many state strategies, and draw conclusions which are published in many of the reports of various organizations and international institutions, which deal with research and study of corruption, stating that judicial system has achieved limited progress in fight against corruption. ${ }^{19}$

Therefore when taking into account all the reports and analysis of foreign organizations as well as local ones, the work of the judiciary, we see that this segment is still hobbled and also need to do more in the future to meet the minimum standards required by international mechanisms and institutions related to the rule of law and respect for human rights and combating crime in Kosovo.

\section{Protection of human rights within the justice system}

The Constitution of the Republic of Kosovo, primarily in the field of protection of human rights, ensures the well-being of citizens; everyone has a duty to respect human rights and fundamental human freedoms. ${ }^{20}$ Evaluation of the implementation or not of this state charter, in relation to the observance of human rights cannot do, without analyzing and evaluating correctly, whether or not the works of these organs in the field of detection and prevention criminality. E.g.: must see how, house burglary committed within a year, which directly attacked, the wealth of citizens, of which the state is obliged under the law to protect the wealth of citizens. How is regulated, organized and supervised the traffic, the disaster actually breathtaking, with considerable damage, which may be the main factor of the state bodies, ( e.g.: no regulation of road transport ministry, central and municipal authorities, not the

\footnotetext{
${ }^{18}$ State Strategy of the Republic of Kosovo, (op., cit.), p. 16.

${ }^{19}$ Kosovo Stability Initiative Progress Report "Made in Kosovo", Pristine, 2010, p. 29.

${ }^{20}$ Article 21, paragraph 3, of the Constitution of Kosovo, 2008.
} 
local or adequate control of traffic by police leaders, not imposition or remission of perpetrators of violations, etc.). Therefore, we can conclude that security of a country other than wars, conflicts, terrorism, measured by the number of crimes committed within a year and the number of persons convicted for offenses within that time period. If the large number of crimes committed, the small number of persons convicted then emphasize that security is crumbling and that citizens are unprotected by the state as required by the laws and constitution of the country, or it's opposite.

But state authorities are limited in case of arrest or investigation until the trial process, to undertake only those actions necessary to develop procedures, especially when it comes to expression, deprivation of liberty. Order Habeas Corpus ${ }^{21}$ is a legal order that compels people to keep someone in custody, to bring to trial. There they must explain the reasons for his detention if the reasons given are not accepted; the judge orders the release of detainees. ${ }^{22}$

Not only prevent, but also in fighting crime, citizen assistance is no substitute for the need to increase the level of cooperation of these bodies with the citizens in fighting crime. Should be encouraged and motivated citizens to report cases when they have the knowledge to perform any action that possesses elements of the offense, and immediately informed the appropriate authorities for such actions.

Among other problems of human rights involving the mistreatment of detainees by police, violence between prisoners, corruption and favoritism in prisons, substandard physical conditions in prisons, pretrial detention and judicial inefficiency, intimidation of the media by public officials elements and criminals, restrictions on religious freedom and vandalism on religious grounds, limited progress in returning internally displaced persons to their homes, violence and irregularities in local elections in some areas, government corruption, anti-Semitic rhetoric, trafficking in persons, poor conditions in mental health facilities, sporadic ethnic tensions in the north and child labor in the informal sector and freedoms. ${ }^{23}$ Respect for human rights is not the right level and considered, that the institutions of police, prosecutors, but the courts often their work, violate the rights and freedoms of human rights in Kosovo.

\section{Conclusions}

The role and importance of judicial institutions anywhere in the world, but also in Kosovo, is a crucial importance in combating and preventing crime. Police, prosecutors

\footnotetext{
${ }^{21}$ Article 1, paragraph 9, United States Constitution, RPO 110037.

${ }^{22}$ The right order, "Habeas Corpus" - cannot be considered only in those cases where, because of insurrection or invasion, so the public safety requires.

${ }^{23}$ State Reports on Practices of Human Rights, the State Department of the United States, the Bureau of Democracy, Human Rights and Labor, 2013, p. 1.
} 
and courts are state institutions which must play their constitutional role in the performance of duties and responsibilities for which they are called and established. Note that so far these institutions of justice in Kosovo, based on the statistics and reports monitoring relevant institutions and organizations, have managed to do enough to fight and prevent crime.

There is no public function successfully performed without supervision, especially supervision of the institution to which separate court justice. If not controlled by works and subjects has, at least once in six months in Parliament, where the proposed special measures to be taken in order to functioning of this segment, and therefore is not straight and is very harmful, estimates given that there is interference in the work of the judiciary, without an analysis by teams of experts.

Constitution and Citizenship expect justice institutions to be established and paid for separate justice and what time of the Romans, which are intended to support and guarantee the continuous and the rule of law, to do their job professionally and independent. Therefore, these bodies in the field of justice, are irreplaceable, fair enforcement policy decisions not undermines public trust in the legal certainty and fair assessment of the issues that affect citizens in how they envisaged the laws and constitution.

With millions of Euro's to invest in the human capacity building infrastructure for the functioning of labor judiciary officials, but little is done to control, supervision and punishment of officials who act inadequately within the justice system in Kosovo.

Protection of human rights and fundamental freedoms in Kosovo, as one of the basic preconditions consider that it is not even close to the required international standards, which are projected with different acts and international conventions.

\section{Bibliography}

1. Begeja Skender, Criminology, Volume I, Tirana, 2001.

2. Demolli Haki, some specifications of the Legal System of the Republic of Kosovo,Journal" Right", Pristina no. 1/2010.

3. Elmedin, Muratbegovic, Compendium of Crime Prevention and Crime Control, Sarajevo, 2007.

4. Gruda, Zejnullah, International Protection of Human Rights, Pristina, 2001.

5. Gjonça Lion, Gjonçaj Genc, Criminology, Tirana, 2009.

6. Halili, Xhevdet, Introduction to the Law of Police, Pristina, 2012.

7. Kosovo Stability Initiative, Progress report called "Made in Kosovo", Pristina, 2010. 
8. Kosovo Institute for Policy Research and Development, KIPRED, 2010.

9. Kosovo Center for Security Studies (KCSF), monitoring and evaluation of good governance in the security sector in Kosovo, Pristina, 2012.

10. The Constitution of Kosovo, since 2008.

11. Latifi, Vesel, Criminal Policy, Pristine. 2008.

12. The Law on the State Prosecutor of the Republic of Kosovo, 2010.

13. Reports State of the Practice of Human Rights, the State Department of the United States, the Bureau of Democracy, Human Rights and Labor, 2013.

14. Rica, Nicholl Judicial Police as the subject of criminal proceedings, Tirana, 2011.

15. Sahiti, Ejup, Murad, Rexhep, Criminal Procedure Law, Pristina, 2013.

16. The State Strategy of the Republic of Kosovo, Organized Crime and Action Plan, 2009.

17. United States Constitution, form 1787. 